\title{
Agro-economic performance of bur gherkin under staking systems ${ }^{1}$
}

\author{
Bruna Garabelli Venturin², João Nacir Colombo², \\ Marcelo Rodrigo Krause ${ }^{3}$, Antonio Fernando de Souza ${ }^{2}$, Ronaldo Luiz Rassele ${ }^{2}$
}

\section{ABSTRACT}

The bur gherkin cultivation is predominantly carried out without a staking system, but problems such as the "white belly" and fruit rot occur in this system. This study aimed to evaluate staking systems for bur gherkin plants. The experimental design was randomized blocks, with five treatments (no staking, agricultural netting staking, Mexican staking, vertical ribbon with total secondary stem thinning and vertical ribbon with alternate secondary stem thinning) and four replicates. The fresh mass and number of fruits per plant, fruit length and average diameter, number and fresh mass of fruits with white belly per plant, fresh mass per fruit and total yield were evaluated, as well as the economic indicators gross income, net income, rate of return and profitability index. For all the staking systems, the incidence of fruits with white belly was lower. The agricultural netting (43.75 $\left.\mathrm{t} \mathrm{ha}^{-1}\right)$, Mexican (35.94 $\left.\mathrm{t} \mathrm{ha}^{-1}\right)$ and vertical ribbon with alternate secondary stem thinning $\left(22.24 \mathrm{t} \mathrm{ha}^{-1}\right)$ systems promoted yields superior to that for no staking. The best economic indicator (US\$21,031.46 ha $\mathrm{has}^{-1}$ ) was observed for the agricultural netting staking, which is the most recommended for the bur gherkin cultivation.

KEYWORDS: Cucumis anguria L., economic indicator, white belly.

\section{INTRODUCTION}

Cucumis anguria L. belongs to the Cucurbitaceae family and can be found in tropical and subtropical regions, extending its occurrence to tropical Africa, Brazil and the Caribbean (Madeira et al. 2008). It is widely consumed in the northern and northeastern regions of Brazil, and its use is of great economic and nutritional interest. It is rich in zinc, an important mineral for the proper functioning of all body tissues,

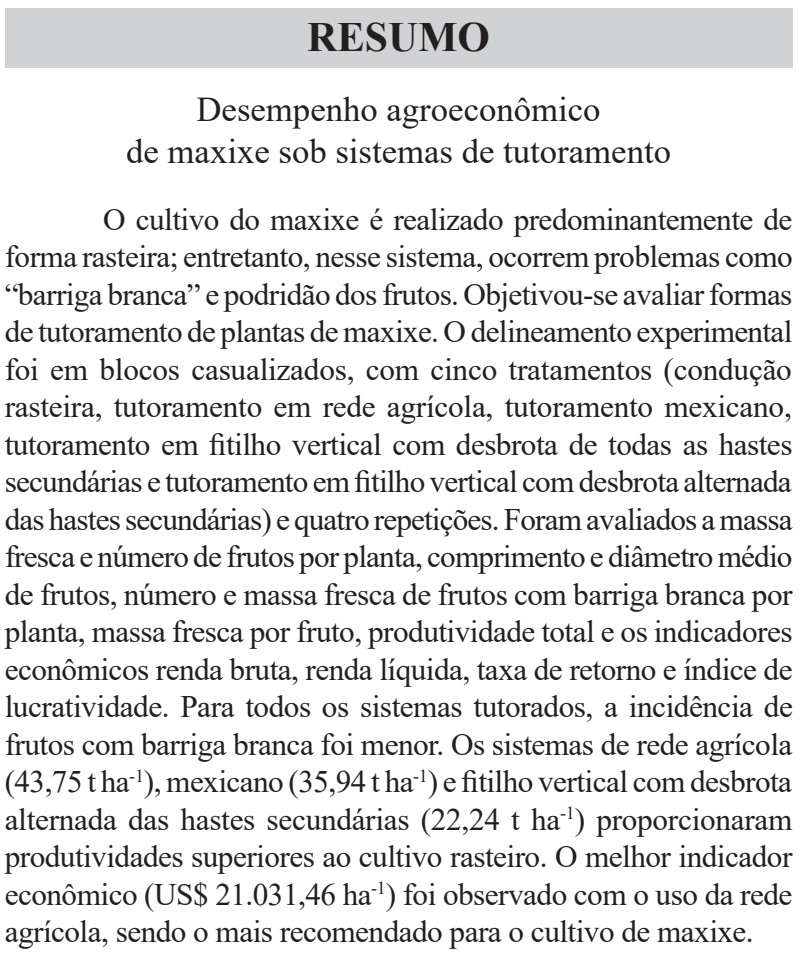

PALAVRAS-CHAVE: Cucumis anguria L., indicador econômico, barriga branca.

and has an antioxidant activity in the fight against free radicals, having no toxic effect on the animal organism (Sousa et al. 2015).

Due to its origin from tropical regions, bur gherkin shows a better development in places and seasons of higher temperatures, not tolerating very low temperatures (Resende 1998). Thus, the Brazilian Espírito Santo state provides adequate conditions for the success of its cultivation. In 2018, 25 ha were cultivated, with a production of $500 \mathrm{t}$ (Incaper 2018).

\footnotetext{
${ }^{1}$ Received: Sep. 15, 2020. Accepted: Nov. 16, 2020. Published: Dec. 09, 2020. DOI: 10.1590/1983-40632020v5065622.

${ }^{2}$ Instituto Federal do Espírito Santo, Santa Teresa, ES, Brasil.E-mail/ORCID: brunaventurin8@gmail.com/ 0000-0002-7508-8639, joaonacirc@yahoo.com.br/0000-0002-2429-5304, anfersouza@gmail.com/0000-0002-4771-097X, ronaldorassele@gmail.com/0000-0003-0057-6803.

${ }^{3}$ Universidade Federal de Viçosa, Departamento de Agronomia, Viçosa, MG, Brasil. E-mail/ORCID: agro.krause@gmail.com/0000-0002-7035-9030.
} 
The authors of the present study have noticed that the entire bur gherkin cultivation in Espírito Santo is carried out with no staking system. However, this system has disadvantages such as the contact between fruits and soil, causing a physiological anomaly known as "white belly", as well as fruit rot. In addition, it is difficult to implement crop practices such as irrigation, weeding and harvesting. The use of staking is a viable alternative to this conventional system. The staking of bur gherkin makes it possible to improve the quality of the harvested fruits, reducing by more than $95 \%$ the occurrence of white belly (Leal et al. 2000).

Among the staking systems, the agricultural netting is used for vegetables or flowers, providing support and staking to the growing system, increasing the cultivation density and allowing the vertical growth of the plant, with an increased circulation between leaves and a decrease in the incidence of pathogens. This system favors the adequate support of plants, facilitating the harvesting and improving the quality of bur gherkin fruits (Modolo \& Costa 2004).

The Mexican staking system consists of conducting the plants vertically between ribbons that are arranged horizontally on both sides of the plant as the stems grow (Wamser \& Mueller 2010). No studies that evaluated the use of Mexican staking in the bur gherkin crop were found; however, it is used by cucumber producers, for peppers (UFV 2012) and for tomatoes (Wamser et al. 2008, Wamser \& Mueller 2010, Schmidt et al. 2018).

Another staking method is the use of a vertical polyethylene ribbon, where the plants are conducted vertically through a raffia ribbon attached to the basal part of the stem of each plant and to a wire located $2 \mathrm{~m}$ high (Modolo \& Costa 2003). However, these authors reported difficulties in this type of staking, since the sprouting and fruiting concentration at the basal area of the plant cause the side branches to be trampled in the final harvesting stages. This shows the dominance of the wild and little domesticated character of bur gherkin, when compared to other species such as cucumber.

Thinning is one of the ways to mitigate the problems with trampling and occurrence of white belly in fruits of bur gherkin plants staked with a vertical ribbon. In the literature, studies have already been conducted to demonstrate the importance of thinning the crop (Modolo \& Costa 2003, Santi et al.
2013). Modolo \& Costa (2003) adopted the protocol used for the cucumber crop, in which the first seven side shoots were eliminated from the base of the main stem. The subsequent shoots were pruned after the appearance of the third fruit on the secondary stem.

The present study aimed to evaluate the agroeconomic performance of bur gherkin cultivated with no staking and with agricultural netting, Mexican and vertical ribbon with total and alternate thinning of secondary stems staking.

\section{MATERIAL AND METHODS}

The study was carried out at the Instituto Federal do Espírito Santo, in Santa Teresa (1948'29'S, $40^{\circ} 41^{\prime} 03^{\prime \prime} \mathrm{W}$ and altitude of $\left.130 \mathrm{~m}\right)$, located in the Central Serrana microregion of the Espírito Santo state, Brazil, from December 2016 to March 2017. The predominant climate is AW (tropical with summer rains), according to the Köppen climatic classification

The experimental design was randomized blocks, with five treatments [no staking, agricultural netting staking, Mexican staking, vertical ribbon with total secondary stem thinning (VRTST) and vertical ribbon with alternate secondary stem thinning (VRAST)] and four replicates. Each experimental unit was represented by four rows of $3.0 \mathrm{~m}$ in length, spaced $1.00 \mathrm{~m}$ apart, resulting in $4 \mathrm{~m}$ width and totaling an area of $12.0 \mathrm{~m}^{2}$. For the no staking treatment, the plants were cultivated at the spacing traditionally used in the region $(2.00 \times 1.00 \mathrm{~m})$, allowing the cultivation of six plants per experimental unit, while, in the other treatments, the spacing was $1.00 \times 0.5 \mathrm{~m}$, totaling 24 plants (Modolo \& Costa 2003).

Seeds of the "caipira do norte" cultivar were purchased in a store, all of the same origin and lot. Sowing was carried out in Styrofoam ${ }^{\mathrm{TM}}$ trays of 128 cells. The seedlings were conducted in a nursery until five days before transplanting, and were then submitted to a period of acclimatization. At 20 days after sowing, the seedlings were transplanted to $20 \times 20 \mathrm{~cm}$ pits, fertilized with 1.5 liters of bovine manure. Fertilizations were carried out following the recommendation for the cucumber crop (Prezotti et al. 2007) and considering the soil analysis, which showed the following characteristics $(0-20 \mathrm{~cm}$ layer $): \mathrm{pH}\left(\mathrm{H}_{2} \mathrm{O}\right)=6.4 ; \mathrm{P}=$ $168 \mathrm{mg} \mathrm{dm}^{-3} ; \mathrm{K}=240 \mathrm{mg} \mathrm{dm}^{-3} ; \mathrm{Ca}^{2+}=4.8 \mathrm{cmol}_{\mathrm{c}} \mathrm{dm}^{-3}$; 
$\mathrm{Mg}^{2+}=1.2 \mathrm{cmol}_{\mathrm{c}} \mathrm{dm}^{-3} ; \mathrm{Al}^{3+}=0.0 \mathrm{cmol}_{\mathrm{c}} \mathrm{dm}^{-3} ; \mathrm{H}+\mathrm{Al}=$ $2.2 \mathrm{cmol}_{\mathrm{c}} \mathrm{dm}^{-3} ; \mathrm{SB}=6.8 \mathrm{cmol}_{\mathrm{c}} \mathrm{dm}^{-3} ; \mathrm{CEC}(\mathrm{t})=6.8$; $\operatorname{CEC}(\mathrm{T})=9.0 \mathrm{cmol}_{\mathrm{c}} \mathrm{dm}^{-3} ; \mathrm{V}=75.5 \% ; \mathrm{OM}=$ $1.9 \mathrm{dag} \mathrm{kg}^{-1} ; \mathrm{B}=0.94 \mathrm{mg} \mathrm{dm}{ }^{-3} ; \mathrm{Fe}=96 \mathrm{mg} \mathrm{dm}^{-3}$; $\mathrm{Mn}=173 \mathrm{mg} \mathrm{dm}^{-3} ; \mathrm{Zn}=8.8 \mathrm{mg} \mathrm{dm}^{-3} ; \mathrm{Cu}=4.6$; $\mathrm{Na}=36 \mathrm{mg} \mathrm{dm}^{-3}$.

For the agricultural netting staking, stakes were fixed into the soil to a depth of $0.5 \mathrm{~m}$, so that they were $2.0 \mathrm{~m}$ above the ground, distanced by $3.0 \mathrm{~m}$. The nets were tied at the top and bottom of the stakes. For the VRTST and VRAST methods, after fixing the stakes, a flat wire 16 was stretched along each cultivation row, at the upper end and at $0.2 \mathrm{~m}$ from the soil. The plants were conducted vertically by a polyethylene ribbon attached to both the lower and the upper wires. For the Mexican staking, the plants were conducted vertically between the horizontally arranged ribbons on both sides of the plants, spaced $20 \mathrm{~cm}$ apart and placed according to their growth.

During the crop development, the paths between the rows were cleared twice and weeds were eliminated around the plant. Irrigation was performed using a sprinkler system, twice a week, in absence of precipitation, in order to keep the soil moist without saturating it. There was no need to carry out phytosanitary control during the experiment.

In the VRTST and VRAST treatments, from the second week after transplanting, weekly thinning was performed. All the side stems were removed from the plants in the VRTST treatment, while, in the VRAST treatment, the thinning was alternated, considering the base (stem) to the apical part of each plant.

Harvesting began at 36 days after transplanting (DAT) and was performed twice a week, until the 13th harvest. Unripe fruits were harvested with seeds not fully developed, around 20 days after anthesis (Modolo \& Costa 2003). In the evaluation, eight plants of the two central rows of the agricultural netting, Mexican, VRTST and VRAST staking treatments were considered useful, while, for no staking, the fruits of two centralized plants were harvested, enabling the evaluation in an area of $4 \mathrm{~m}^{2}$ for all the treatments. After harvesting, the fruits were classified according to absence or presence of white belly, weighed and counted, providing conditions to evaluate the following variables: fruit fresh mass per plant; number of fruits per plant; fruit average length; fruit average diameter; number of fruits with white belly per plant; mass of fruits with white belly per plant; average fruit fresh mass; and total yield.
Using the yield data, the efficiency of the systems was evaluated by the following economic indicators: gross income; net income; rate of return; and profitability index. To calculate the gross income, the average nominal wholesale price in FebruaryMarch at the CEASA-ES of Cariacica (Espírito Santo state - ES) was considered. The net income was obtained by the difference between the gross revenue and total operating cost, while the latter was calculated from the technical coefficients for production cost of bur gherkin (Emater - DF 2017), with modifications based on the operations and input needs presented in the experiment. The costs related to inputs, services, packaging and transport were calculated from the prices practiced in the city of Santa Teresa - ES, from December 2016 to March 2017. The rate of return per invested dollar (US\$) in each treatment was obtained by the relation between the gross income and the production cost. The profitability index was obtained from the relation between gross income and net income, and expressed as percentage (Cecílio Filho et al. 2008).

The variables were submitted to the normality (Lilliefors) and homoscedasticity (Levene) tests required for the validation of the analysis of variance. The variables number of fruits with white belly per plant, fresh mass of fruits with white belly per plant and total yield were respectively transformed into $\log (\mathrm{x}), \log (\mathrm{x})$ and $4 \sqrt{ } \mathrm{x}$, to meet the assumptions of the analysis of variance. For comparison between no staking (control) and the staking methods, the data were compared using contrast by the Scheffé and Tukey tests. All statistical analyses were performed by the R software, version 3.4.4, adopting an $\alpha$ of up to 0.05 (R Core Team 2018).

\section{RESULTS AND DISCUSSION}

In Table 1, it is possible to compare the values for fruit fresh mass per plant, number of fruits per plant, fruit average length, fruit average diameter, number of fruits with white belly per plant, mass of fruits with white belly per plant, average fruit fresh mass and total yield, in the cultivation of bur gherkin with no staking, as a function of the staking methods used.

There was a significant difference for the number of fruits and mass of fruits with white belly per plant, with average values for staking treatments lower than those for no staking, and for total yield, 
Table 1. Coefficients, estimators and significance levels of the contrasts between no staking (control) and agricultural netting, Mexican, vertical ribbon with total secondary stem thinning (VRTST) and vertical ribbon with alternated secondary stems thinning (VRAST) stakings for bur gherkin.

\begin{tabular}{|c|c|c|c|c|c|c|c|}
\hline \multirow{2}{*}{ Variables } & \multicolumn{5}{|c|}{ Treatments } & \multirow{2}{*}{ Estimator } & \multirow{2}{*}{ Error $\alpha$} \\
\hline & No staking & Netting & Mexican & VRTST & VRAST & & \\
\hline Contrast coefficient & 4 & -1 & -1 & -1 & -1 & - & - \\
\hline FFMP $(g)$ & $1,820.17$ & $2,187.27$ & $1,797.20$ & 843.54 & $1,111.92$ & $335.188^{\mathrm{ns}}$ & 0.2547 \\
\hline NFP (un) & 49.47 & 58.27 & 52.77 & 21.94 & 32.77 & $8.035^{\mathrm{ns}}$ & 0.3101 \\
\hline NFWBP (un) & 49.32 & 10.83 & 19.59 & 0.19 & 9.46 & $1.036^{*}$ & $<0.0001$ \\
\hline MFWBP (g) & $1,813.55$ & 417.99 & 646.26 & 7.26 & 321.46 & $1.056^{*}$ & $<0.0001$ \\
\hline FFM $(g)$ & 38.37 & 38.80 & 33.93 & 38.81 & 34.00 & $1.989^{\mathrm{ns}}$ & 0.3133 \\
\hline $\mathrm{D}(\mathrm{cm})$ & 3.38 & 4.09 & 3.40 & 3.45 & 3.24 & $-0.168^{\mathrm{ns}}$ & 0.6258 \\
\hline $\mathrm{L}(\mathrm{cm})$ & 5.85 & 6.00 & 5.74 & 5.67 & 5.41 & $0.144^{\mathrm{ns}}$ & 0.3502 \\
\hline Yield $\left(\mathrm{t} \mathrm{ha}^{-1}\right)$ & 9.10 & 43.75 & 35.94 & 16.87 & 22.24 & $-0.564 *$ & 0.0001 \\
\hline
\end{tabular}

FFMP: fruit fresh mass per plant; NFP: number of fruits per plant; NFWBP: number of fruits with white belly per plant; MFWBP: mass of fruits with white belly per plant; FFM: average fruit fresh mass; D: fruit average diameter; L: fruit average length.

where the staking treatments were superior than for no staking.

This result demonstrates the importance of staking in the bur gherkin crop, for the reduction of fruits with white belly, as well as in the increase of yield due to the better spatial distribution of the plants in the area, promoting a higher density. There was no significant difference for number of fruits and mass per plant (Table 1). Thus, more plants per hectare and a better distribution of solar radiation in the staking systems likely promoted a greater yield.

Modolo \& Costa (2004) evaluated the production of the Paulista variety of bur gherkin with agricultural netting staking and verified that it facilitates the harvesting operation, as well as improves the fruit quality. This behavior was also observed by Costa et al. (2019), who verified a higher quality of fruits during the cultivation on trellis system. Costa et al. (2005), evaluating the production of Cyclanthera pedata as a function of the staking system and spacing, verified that the fruit yield per hectare was significantly higher in plants grown in the vertical system.

The staking system also increased the fruit production of other cucurbits. In the cucumber crop, there was an increase of 9.29 fruits per plant with staking, in comparison with no staking, as well as a higher fruit quality (Boeno et al. 2012). In the management of physalis (Physalis angulata), a plant belonging to the Solanaceae family, to obtain a higher yield and fruit quality, it is necessary to use a conduction system with staking and thinning (Muniz et al. 2011).

White belly occurs when fruits of dark green color develop in contact with the soil. The portion that does not receive solar radiation becomes white, what is related to chlorophyll degradation. To avoid white belly, fruit rotation or plant staking can be performed. White belly has been a problem in the commercialization of fruits in more demanding markets, since it directly affects their appearance. For no staking, the direct contact of fruits with the soil prevents the distribution of light throughout their surface, causing the presence of whitish spots. Due to the more uniform exposure of all parts of the fruit to radiation in the staking system, this problem is suppressed, leaving the fruits with a uniform green color. This system allows the possibility of a greater number of plants per area, thus increasing yield, what makes the staking technique promising for the bur gherkin cultivation.

Table 2 shows the average values for fruit fresh mass per plant, number of fruits per plant, fruit average length, fruit average diameter, number of fruits with white belly per plant, mass of fruits with white belly per plant, average fruit fresh mass and yield of the evaluated bur gherkin, considering the no staking and staking systems used.

According to the results presented in Table 2, there was no significantdifference among the treatments, when analyzing the variables fruit diameter and length $(\mathrm{p}<0.05)$. A similar result was observed by Costa et al. (2005), who did not find a significant difference for the same variables, when evaluating three types of staking: vertical wire, cross wire with sticks and cross wire with polyethylene ribbon.

Regarding the incidence of white belly on the fruits, the highest values were observed for no staking and, among the staking treatments, the use of VRTST 
Table 2. Fruit fresh mass per plant (FFMP), total number of fruits per plant (NFP), number of fruits with white belly per plant (NFWBP), fresh mass of fruits with white belly per plant (FMFWBP), average fruit fresh mass (FFM), fruit average length (L), fruit average diameter (D) and total yield of bur gherkin fruits grown under staking systems.

\begin{tabular}{|c|c|c|c|c|c|c|}
\hline \multirow{2}{*}{ Variables } & \multicolumn{5}{|c|}{ Treatments } & \multirow{2}{*}{ Error $\alpha$} \\
\hline & No staking & Netting & Mexican & VRTST $^{1}$ & VRAST $^{2}$ & \\
\hline$\overline{\text { FFMP (g) }}$ & $1,820.17 \mathrm{ab}^{*}$ & $2,187.27 \mathrm{a}$ & $1,797.20 \mathrm{ab}$ & $843.54 \mathrm{~b}$ & $1,111.92 \mathrm{ab}$ & 0.0142 \\
\hline NFP (un) & $49.47 \mathrm{ab}$ & $58.27 \mathrm{a}$ & $52.77 \mathrm{a}$ & $21.94 \mathrm{~b}$ & $32.77 \mathrm{ab}$ & 0.0133 \\
\hline NFWBP (un) & $49.32 \mathrm{a}$ & $10.83 \mathrm{~b}$ & $19.59 b$ & $0.19 \mathrm{c}$ & $9.46 \mathrm{~b}$ & $<0.0001$ \\
\hline FMFWBP (g) & $1,813.55 \mathrm{a}$ & $417.99 \mathrm{~b}$ & $646.26 \mathrm{~b}$ & $7.26 \mathrm{c}$ & $321.46 \mathrm{~b}$ & $<0.0001$ \\
\hline FFM $(g)$ & $38.37 \mathrm{a}$ & $38.80 \mathrm{a}$ & $33.93 \mathrm{a}$ & $38.81 \mathrm{a}$ & $34.00 \mathrm{a}$ & 0.1155 \\
\hline $\mathrm{D}(\mathrm{cm})$ & $3.38 \mathrm{a}$ & $4.09 \mathrm{a}$ & $3.40 \mathrm{a}$ & $3.45 \mathrm{a}$ & $3.24 \mathrm{a}$ & 0.3466 \\
\hline $\mathrm{L}(\mathrm{cm})$ & $5.85 \mathrm{a}$ & $6.00 \mathrm{a}$ & $5.74 \mathrm{a}$ & $5.67 \mathrm{a}$ & $5.41 \mathrm{a}$ & 0.0745 \\
\hline Yield $\left(\mathrm{t} \mathrm{ha}^{-1}\right)$ & $9.10 \mathrm{c}$ & $43.75 \mathrm{a}$ & $35.94 \mathrm{a}$ & $16.87 \mathrm{bc}$ & $22.24 \mathrm{ab}$ & 0.0001 \\
\hline
\end{tabular}

* Means followed by the same letter are equal to each other by the Tukey test at $5 \%$ of probability. ${ }^{1}$ VRTST: vertical ribbon with total secondary stem thinning; ${ }^{2}$ VRAST: vertical ribbon with alternate secondary stem thinning.

led to the lowest values, possibly due to the removal of all side shoots, reducing the weight of stems and fruits and preventing the fruits from being in contact with the soil. The management of staked bur gherkin has some difficulties in the conduction of the crop. Both in the Paulista bur gherkin and in the normal one, there is a strong side budding in the basal part of the stem (Modolo \& Costa 2003). The concentration of sprouting and fruiting in the basal area of the stem makes the side branches to be trampled at the final harvesting stages (Modolo \& Costa 2003). Thus, in the present study, the removal of all lateral stems caused the plants to be better conducted, reducing the risk of the fruits coming into contact with the soil. However, there was a reduction in the number of fruits and fresh mass per plant, affecting the crop yield (Table 2).

The treatments with agricultural netting, Mexican and VRAST staking did not show significant differences from one another for any of the evaluated variables, being all superior to no staking for yield and inferior for incidence of white belly, proving to be the best types of staking for the bur gherkin crop. The production of Paulista bur gherkin supported by agricultural netting promotes good yields (Modolo \& Costa 2004). It should be noted that their highest yield (39.35 $\left.\mathrm{t} \mathrm{ha}^{-1}\right)$ was lower than that observed in the present study (43.75 $\left.\mathrm{t} \mathrm{ha}^{-1}\right)$.

The yield achieved in this study with the use of agricultural netting staking was also higher than that verified by Costa et al. (2005), who evaluated the performance of bur gherkin under different staking systems. The highest value was obtained with vertical wire (33.86 tha $\left.\mathrm{th}^{-1}\right)$, exceeding the values obtained with crossed ribbon and stake. The vertical wire system resembles the vertical staking with ribbon used in the present study; however, Costa et al. (2005) did not perform the thinning of the stems, conducting the plants through tying.

Among the staking systems, the agricultural netting was efficient for bur gherkin cultivation (Modolo \& Costa 2004), and the Mexican system was inferior to the individual bamboo staking system and similar to the spiral system in the production of tomato fruits (Schmidt et al. 2018). Thus, it did not show a significant difference, in comparison to the crossed wire system, vertical system with bamboo and vertical ribbon in the incidence of black spot, bacterial spot, tomato blight and fruit borer (Wamser et al. 2008). Santi et al. (2013), using the vertical system with ribbon in Japanese cucumber, found that stem-conducted plants without lateral sprouting have a total yield higher than those of plants conducted with two and three stems without lateral sprouts and those with only one stem with lateral sprouts remaining. In the present study, the removal of all the lateral buds negatively affected the bur gherkin production, showing that it did not have the same response to the cucumber lateral stems pruning protocol (Modolo \& Costa 2003).

Table 3 lists the costs related to the inputs and manpower required for the implementation of 1 ha of bur gherkin conducted under different systems.

The highest total operating cost was observed for the Mexican treatment. Among the most expensive items, it is worth mentioning the harvest labor. The Mexican system in tomato leads to lodging, caused by the weight of the fruits on the plant (Schmidt et 
Table 3. Total operating cost of bur gherkin cultivated under different conducting systems.

\begin{tabular}{|c|c|c|c|c|c|}
\hline \multirow{2}{*}{ Items } & \multicolumn{5}{|c|}{ - Treatments (US\$ ha-1) } \\
\hline & No staking & Netting & Mexican & VRTST $^{1}$ & VRAST $^{2}$ \\
\hline \multicolumn{6}{|l|}{ Inputs } \\
\hline Seedlings & 8.33 & 32.69 & 32.69 & 32.69 & 32.69 \\
\hline Stakes & - & 598.29 & 598.29 & 598.29 & 598.29 \\
\hline Ribbon & - & $2,082.31$ & $1,025.38$ & 549.42 & 549.42 \\
\hline Wire & - & - & - & 139.04 & 139.04 \\
\hline Organic fertilizer & 312.50 & $1,250.00$ & $1,250.00$ & $1,250.00$ & $1,250.00$ \\
\hline \multicolumn{6}{|l|}{ Labor } \\
\hline Soil preparation & 168.27 & 673.08 & 673.08 & 673.08 & 673.08 \\
\hline Conducting/staking & - & 487.18 & 615.38 & 256.41 & 256.41 \\
\hline Thinning & - & - & - & 256.41 & 538.46 \\
\hline Irrigation & 44.87 & 44.87 & 44.87 & 44.87 & 44.87 \\
\hline Pruning/weeding & 134.61 & 269.23 & 269.23 & 269.23 & 269.23 \\
\hline Harvesting & $3,461.54$ & $2,307.69$ & $4,615.38$ & 666.67 & $1,384.61$ \\
\hline Total operating cost & $4,130.12$ & $7,745.34$ & $9,124.30$ & $4,736.11$ & $5,736.10$ \\
\hline
\end{tabular}

al. 2018). That was also observed in the bur gherkin conduction, making it difficult to observe and harvest the fruits between the plants, because of the presence of small thorns.

The staking systems that stimulated the highest vertical growth of the plants promoted lower costs in the harvesting operation, due to the ease in observing the fruits, as well as in the improvement of the ergometric conditions at the time of the activity. The lateral sprout also influenced the harvesting activity, evidenced by the lower cost (US\$ 666.67) verified in the treatment in which the vertical ribbon was used with thinning of all lateral sprouts.

The no staking treatment was the one with the lowest value (Table 3 ). A similar result was verified by Guimarães et al. (2017), when evaluating several staking systems and planting distances in the bean crop. In the no staking system, thinning and staking were not used, reducing costs in the operations of the bur gherkin crop.

Table 4 shows the economic indicators of the bur gherkin crop cultivated under different staking systems.

According to Table 4, it can be observed that the treatment in which agricultural netting staking was used was the one that had the best economic indicators, due to the higher yields achieved (Tables 1 and 2). Although the anomaly known as white belly affects the quality of the fruits, they are often commercialized, and they were also computed in the calculations to obtain the economic indicators.
Table 4. Gross income (GI), net income (NI), rate of return (RR) and profitability index (PI) of bur gherkin cultivated under different staking systems.

\begin{tabular}{lrrrr}
\hline \multicolumn{1}{c}{ Treatments } & GI $\left(\mathrm{US} \$\right.$ ha $\left.^{-1}\right)$ & NI $\left(\mathrm{US} \$ \mathrm{ha}^{-1}\right)$ & $\mathrm{RR}$ & $\mathrm{PI}(\%)$ \\
\hline No staking & $4,368.00$ & 237.88 & 1.06 & 5.00 \\
Netting & $21,031.46$ & $13,286.12$ & 2.71 & 63.17 \\
Mexican & $17,251.20$ & $8,126.90$ & 1.89 & 47.11 \\
VRTST $^{1}$ & $8,097.60$ & 3361.49 & 1.71 & 41.51 \\
VRAST $^{2}$ & $10,675.20$ & $4,939.10$ & 1.86 & 46.27 \\
\hline
\end{tabular}

${ }^{1}$ VRTST: vertical ribbon with total stem thinning; ${ }^{2}$ VRAST: vertical ribbon with alternate stem thinning.

Modolo \& Costa (2004) verified the efficiency of this staking system of bur gherkin. In general, the treatments in which the plants were staked led to higher values than for no staking. The use of staking also increased the gross income and net income of physalis (Physalis peruviana L.), which, when staked on a trellis system, showed values higher than those for no staking (Muniz et al. 2011).

Among the studies that evaluated the economic profitability of the bur gherkin crop, Brito et al. (2017) verified a profitability index of $86.5 \%$, in a pergola staking system with plants spaced by $1.0 \times 0.9 \mathrm{~m}$. This result is higher than that found in the present study with the use of agricultural netting staking (63.17\%). Despite that, yields lower than those observed in the present study with the use of agricultural netting staking were found by Modolo \& Costa 2004 and Costa et al. 2005, demonstrating that, during the economic analysis, factors such as the 
price offered by the market at the time of harvesting, mainly influenced by the climatic conditions, are important and should be considered.

Studies that evaluated the rate of return and profitability index in horticulture show a great variability in the values found. For the cucumber crop, which belongs to the same family of bur gherkin, rate of return values ranging from 1.19 to 1.39 and profitability index values from 15.75 to $27.84 \%$ were obtained, when cultivated with $30 \mathrm{~cm}$ distanced plants or two $60 \mathrm{~cm}$ distanced plants (Colombo et al. 2018). In the cultivation of Italian zucchini, also a species belonging to the cucurbit family, rate of return values from 4.64 to 4.82 and profitability index values from 78 to $79 \%$ were obtained (Fukushi et al. 2018).

The agricultural netting and the Mexican staking systems were the ones that led to the highest yields, as well as a reduction in the number and fresh mass of fruits with white belly. When an economic analysis was performed, the indices were higher for the agricultural netting staking system than for the Mexican one, showing that agricultural netting is the most indicated system for the bur gherkin crop.

\section{CONCLUSIONS}

1. The bur gherkin staking using the Mexican, agricultural netting and vertical ribbon with alternate secondary stem thinning systems promotes an increase in yield, when compared to no staking;

2. The bur gherkin staking reduces the production of fruits with white belly;

3. Better economic indicators for the cultivation of bur gherkin are obtained with agricultural netting staking, being this the most indicated system.

\section{REFERENCES}

BOENO, R. S.; PINTO, J. P.; GOMES, M. J. C.; ZANUZO, M. R.; CORASSA, J. N.; WOBETO, C. Efeito de diferentes sistemas de tutoramento sobre parâmetros qualitativos e quantitativos de frutos de pepino. Horticultura Brasileira, v. 30, n. 2, p. 2336-2345, 2012.

BRITO, A. B.; PUIATTI, M.; CECON, P. R.; FINGER, F. L.; DRUMMOND, T. C. M. Viabilidade agroeconômica dos consórcios taro com brócolis, couve-chinesa, berinjela, jiló, pimentão e maxixe. Revista Brasileira de Ciências Agrárias, v. 12, n. 3, p. 296-302, 2017.
CECÍLIO FILHO, A. B.; COSTA, C. C.; REZENDE, B. L. A.; LEEUWEN, R. Viabilidade produtiva e econômica do consórcio entre chicória e rúcula em função da época de plantio. Horticultura Brasileira, v. 26, n. 3, p. 316320, 2008.

COLOMBO, J. N.; PUIATTI, M.; SILVA FILHO, J. B. da; VIEIRA, J. C. B.; SILVA, G. C. C. Viabilidade agroeconômica do consórcio de taro (Colocasia esculenta L.) e pepino em função do arranjo de plantas. Revista Ceres, v. 65, n. 1, p. 56-64, 2018.

COSTA, C. A.; RAMOS, J.; ALVES, D. S.; MARTINS, E. R.; FERNANDES, L. A.; LEITE, G. L. D.; NAPOLEÃO, R. L. Produção do maxixe-do-reino em função do sistema de tutoramento e do espaçamento. Horticultura Brasileira, v. 23 , n. 1, p. 28-31, 2005.

COSTA, H. G.; FERREIRA, E.; FERREIRA, A. F. T. A.; NODA, H.; BENTES, J. L. S. Produtividade de cultivares de maxixe em diferentes sistemas de cultivo. Revista Agrária Acadêmica, v. 2, n. 1, p. 38-46, 2019.

EMPRESA DEASSISTÊNCIA TÉCNICAE EXTENSÃO RURAL DO DISTRITO FEDERAL (Emater - DF). Custo de produção do maxixe. 2017. Available at: http://www. emater.df.gov.br/. Access on: July 15, 2020.

FUKUSHI, Y. K. M.; JUNQUEIRA, A. M. R.; TELLES, C. C.; KOYAMA, A. H.; SOUSA, M. A. C.; SILVA, T. C. Viabilidade econômica do cultivo das hortaliças abobrinha italiana e repolho em sistema de base agroecológica consorciado. Cadernos de Agroecologia, v. 13, n. 1, p. 1-6, 2018.

GUIMARÃES, M. A.; LEMOS NETO, H. S.; ARAÚJO, R. B.; LIMA NETO, B. P.; SILVA, V. B.; MESQUITA, R. O. Sistemas de tutoramento e espaçamentos de plantio na produção de feijão de metro. Horticultura Brasileira, v. 35, n. 4, p. 613-620, 2017.

INSTITUTO CAPIXABA DE PESQUISA, ASSISTÊNCIA TÉCNICA E EXTENSÃO RURAL (Incaper). Boletim da conjuntura agropecuária capixaba. 2018. Available at: https://biblioteca.incaper.es.gov. br/digital/bitstream/123456789/3394/1/Boletim-daconjuntura-Agropecuaria-Ano-IV-n-16-Dezembrode-2018.pdf. Access on: Nov. 24, 2020.

LEAL, F. R.; SANTOS, V. B.; SAlVIANO, A. A. C. Sistemas de condução e aplicação de cal extinta na cultura do maxixe. Horticultura Brasileira, v. 18, supl., p. 542$543,2000$.

MADEIRA, N. R.; REIFSCHNEIDER, F. J. B.; GIORDANO, L. B. Contribuição portuguesa à produção $\mathrm{e}$ ao consumo de hortaliças no Brasil: uma revisão histórica. Horticultura Brasileira, v. 26, n. 4, p. 428-432, 2008. 
MODOLO, V. A.; COSTA, C. P. Avaliação de linhagens de maxixe Paulista em ambiente protegido. Horticultura Brasileira, v. 21, n. 4, p. 632-634, 2003.

MODOLO, V. A.; COSTA, C. P. Production of Paulista gherkin using trellis net support. Scientia Agricola, v. 61, n. 1, p. 43-46, 2004.

MUNIZ, J.; KRETZSCHMAR, A. L.; RUFATO, L.; PELIZZA, T. R.; MARCHI, T.; DUARTE, A. E.; FERNANDES, A. N. L. P.; GARANHANI, F. Sistemas de condução para o cultivo de physalis no planalto catarinense. Revista Brasileira de Fruticultura, v. 33, n. 3, p. 830-838, 2011.

PREZOTTI, L. C.; GOMES, J. A.; DADALTO, G. G.; OLIVEIRA, J. A. Manual de recomendação de calagem e adubação para o estado do Espírito Santo: $5^{\text {a }}$ aproximação. Vitória: SEEA/Incaper/Cedagro, 2007.

R CORE TEAM. $R$ : a language and environment for statistical computing. Vienna: R Foundation for Statistical Computing, 2018.

RESENDE, G. M. Rendimento de cultivares de maxixe em função de épocas de plantio. Horticultura Brasileira, v. 16, n. 2, p. 167-171, 1998.

SANTI, A.; SCARAMUZZA, W. L. M. P.; SOARES, D. M. J.; SCARAMUZZA, J. F.; DALLACORT, R.;
KRAUSE, W.; TIEPPO, R. C. Desempenho e orientação do crescimento do pepino Japonês em ambiente protegido. Horticultura Brasileira, v. 31, n. 4, p. 649-653, 2013.

SCHMIDT, J.; MENEGUELLI, C. M.; KRAUSE, M. R.; HELL, M. V.; OLIVEIRA, M. L.; COLOMBO, J. N.; HADDADE, I. R. Desempenho do tomateiro em sistema de tutoramento vertical em espiral conduzido com uma ou duas hastes. Nativa, v. 6, n. 4, p. 338-444, 2018.

SOUSA, A. P. B.; LIMA, F. G. S.; LIMA, A. Propriedades nutricionais do maxixe e do quiabo. Revista Saúde em Foco, v. 2, n. 1, p. 113-129, 2015.

UNIVERSIDADE FEDERAL DE VIÇOSA (UFV). Pimentão: cultivo em ambiente protegido. 2012. Available at: https://www.pimentaoufv.blogspot.com. Access on: July 18, 2020.

WAMSER, A. F.; BECKER, W. F.; SANTOS, J.; MUELLER, S. Influência do sistema de condução do tomateiro sobre a incidência de doenças e insetos praga. Horticultura Brasileira, v. 26, n. 2, p. 180-185, 2008.

WAMSER, A. F.; MUELLER, S. Curvatura da base do caule do tomateiro afetada por métodos de tutoramento e sua relação com a produtividade de frutos. Agropecuária Catarinense, v. 23, n. 1, p. 49-52, 2010. 